\title{
The Role of Geographical Indications in Agricultural Sustainability and Economic Development
}

\section{Blakeney M*}

Institute of Agriculture, University of Western Australia, Australia

*Correspondling author: Michael Blakeney, Institute of Agriculture, University of Western Australia, School of Law, 35 Stirling Highway, CRAWLEY, WA 6009, Australia

Received: J anuary 13, 2021; Accepted: February 10, 2021; Published: February 17, 2021

\begin{abstract}
This article examines the role which Geographical Indications (GIs) can play in promoting agricultural sustainability and economic development in developing countries and Least Developed Countries (LDCs). After defining geographical indications in relation to agricultural products and foodstuffs, the article reviews the literature concerning: GIs and market differentiation; GIs and premium pricing; their role in the certification of product quality and in the aggregation of market power. The role of Gls in promoting the sustainable use of natural resources and biodiversity conservation and their value in promoting rural development in developing countries and LDCs.
\end{abstract}

Keywords: Geographical indications; Product differentiation; Certification of product quality; Premium prices; Sustainable agriculture; Biodiversity conservation; Rural development

\section{Introduction}

Agriculture is the backbone of the economy of low-income countries. It accounts for around 60 percent of Gross Domestic Product (GDP) employs a large proportion of the labour force from 40 percent to as much as 90 percent, represents a major source of foreign exchange and supplies the bulk of basic food and provides subsistence and other income to more than half of the population, particularly in LDCs [1]. This is to be contrasted with middle-income countries with agriculture contributing only 9 percent of GDP and 1 percent in high-income countries [2]. Agriculture being the main source of livelihood in low-income countries can also be an engine of growth and an effective tool for poverty reduction.

Increases in the productivity and profitability of agriculture can increase the income of the rural population, thereby creating demand for domestically produced agricultural and industrial products [3]. Agricultural goods can be exported to earn foreign exchange enabling the importation of capital goods and technology, as well as agricultural inputs such as seeds, fertilizer, irrigation equipment and storage facilities, and food supplies. This article will consider how Geographical Indications (GIs) can enhance the role of agriculture in economic development.

\section{Geographical Indications}

GIs are signs used to designate the place of origin of goods where a given quality, reputation or other characteristic of the good is essentially attributable to its geographical origin. This may be because of climatic factors, as well as human inputs.

The obligation of countries to protect geographical indications is contained in Article 22.2 of the World Trade Organization (WTO) Agreement on Trade Related Aspects of Intellectual Property Rights ('TRIPS'). This provision requires WTO Members to provide the legal means for interested parties to prevent:

(a) The use of any means in the designation or presentation of a good that indicates or suggests that the good in question originates in a geographical area other than the true place of origin in a manner, which misleads the public as to the geographical origin of the good;

(b) any use which constitutes an act of unfair competition within the meaning of Article 10bis of the Paris Convention (1967).

The TRIPS Agreement does not prescribe how countries might legislate to prevent the misuse of GIs. Giovannucci et al., [4] explain that 111 countries have enacted sui generis legislation to protect GIs as a distinct IP category while 56 countries rely upon the protection of GIs through trademark laws. Sui generis protection is that specially enacted to deal with this particular category of Intellectual Property ('IP') right. Sui generis protection of GIs originated in Europe to protect foodstuffs, wines and spirits [5]. This generally involves only collective applications by producers for GI protection, through a system requiring written product specifications are required, containing a definition of the geographical boundaries delineating where the GI production is recognized, a justification of the linkage between the territory and the quality of the GI product, the characteristics of both the production process and the quality of raw materials, and the definition of the final product. Another typical ingredient of sui generis systems is third-party inspection and certification which acts as a guarantee that products comply with the specifications and a collective organization to manage the GI. In Europe agricultural consortia have been established by producers to manage their GIs. This is obviously a significant financial burden for producers in developing countries and LDCs, but state-sponsored bodies, agricultural universities and farmers' collectives have begun to take on this role. For example, in relation to traditional rice varieties in Kerala, GIs have been obtained for 'Navara' rice by the Navara Rice Farmers Society, for 'Pokkali' rice by the Pokkali Land Development Society and Kerala Agricultural University (KAU), for 'Wayanad Jeerakasala Rice' by the Wayanad Zilla Nellulpadaka Karshaka Samithi (a farmers' collective), for 'Kaipad Rice' by the Malabar Kaipad Farmers' Society and for 'Palakkadan Matta Rice' by 
the Palakkad Matta Farmers Producer Company Ltd [6].

The first EU legislation on GIs was Regulation 2081/92 on the protection of geographical indications and designations for agricultural products and foodstuffs. This Regulation was considered by a WTO dispute panel to be in breach of the TRIPS Agreement, because it discriminated against non-European GIs and this regulation was repealed and replaced by Council Regulation (EC) No 510/2006 of 20 March 2006. On 21 November 2012, the 2006 Regulation was replaced by Regulation (EU) No 1151/2012 on quality schemes for agricultural products and foodstuffs as part of a policy of prioritising innovation in agriculture ('Quality Schemes Regulation').

A number of the objectives of this legislation are equally of relevance to developing countries and LDCs. Recital (2) to the Quality Schemes Regulation observes that EU consumers 'increasingly demand quality as well as traditional products' and are also concerned to maintain the diversity of the agricultural production, which 'generates a demand for agricultural products or foodstuffs with identifiable specific characteristics, in particular those linked to their geographical origin'. Recital (4) suggests that operating quality schemes for producers which reward them for their efforts to produce a diverse range of quality products can benefit the rural economy, particularly in less favoured areas, in mountain areas and in the most remote regions, where the farming sector accounts for a significant part of the economy and production costs are high.

The EU has been very active in promoting its style of GIs protection, particularly among the developing countries and LDCs of Africa, the Caribbean and the Pacific [7,8]. Alternative approaches to the protection of GIs involve the use of certification and collective trademarks. These are marks, which can be used by producers who meet prescribed certification standards. The marks are registered by the certifying authorities, which are not involved in the production of the relevant origin product. Detailed below are some of the arguments which have been put forward to justify countries' adopting GIs protection, which are relevant to the promotion of agricultural sustainability and economic development.

\section{GIs and Market Differentiation}

Agricultural producers in developing countries and LDCs have the challenge of securing market access in the valuable markets of industrialised countries by differentiating their products from those of other agricultural producers. GIs provide a mechanism for the producers of agricultural products to allow them to differentiate their products from general commodity categories such as rice, coffee and tea, by establishing territorially differentiated niche markets $[9,10]$. GIs disconnect origin products from commodity markets by capturing attributes of the locality such as environmental factors and local knowledge [11,12]. Ittersum et al., [13] made the point that although origin-based marketing has a long history, its contemporary relevance is increasing, partly as a reaction to globalization as local producers need to be able to distinguish their product in the eyes of consumers from generic competition. In the newly urbanising developing countries consumers and people from a particular region or ethnic group look to the products from their places of origin as being reliable and known. Gradually, these local products begin to gain a commercial reputation among a wider group of traders and consumers. By way of example, origin products from developing countries and LDCs which have been differentiated from commodity products are: Indian Basmati rice and Darjeeling tea, Kintamani Bali coffee and Muntok White Pepper from Indonesia, Blue Mountain coffee from Jamaica, Rwandan coffee, Rooibos tea and Karoo lamb, from South Africa, Buon Ma Thuot coffee and Me'o Vac Mint Honey, from Vietnam, Man mountain rice from Côte d'Ivoire, Mamou pepper and Boké palm oil from Guinea, Oku white honey from Cameroon, Surin Hom Mali scented rice and Jasmine rice from Thailand [14-17].

\section{GIs and Premium Pricing}

A number of researchers have identified the capacity of origin labelling to differentiate otherwise homogeneous commodities as the basis for charging premium prices. Reviron et al., [18] refer to value addition from a mix of economic, cultural and social characteristics leading to the capturing of a premium price. Marette and Williams $[19,20]$ assert the higher value which consumers attach to products differentiated according to their origin.

Babcock [21] reported that Bresse poultry in France receives quadruple the commodity price for poultry meat; Italian "Toscano" oil gains a $20 \%$ premium above commodity oil; and milk supplied to produce French Comte cheese sells for a 10\% premium. The case study of Comte cheese in France by Gerz and Dupont [22] indicated that French farmers receive an average of 14 more for milk destined for Comte and that dairy farms in the Comte area have become more profitable since 1990, and now are 32 per cent more profitable than similar farms outside the Comte area. The retail price of Comte has risen by 2.5 per cent, annually while the wholesale price has risen by 1.5 per cent a year. The French Ministry of Agriculture claims that part of this added value accrues to producers and other actors in the Comte supply chain, whereas retailers have appropriated all of the $0.5 \%$ rise in the retail price of Emmental [23]. O'Connor and Company [24] refer to the protection of 'Lentilles vertes du Puy', which is said to have increased the production of lentils from 13,600 quintals in 1990 to 34,000 quintals in 1996 and 49,776 quintals in 2002, the number of producers almost tripling from 395 in 1990, to 750 in 1996, and 1,079 in 2002. In a study of Hessian apple wine, Teuber [25] indicated that the willingness of consumers to pay a premium price is because of their view of the positive impacts of GIs on the local economy.

There are fewer studies of premium prices for origin products outside Europe. Kireeva et al., [26] examine a number of examples of the use certification marks in the Peoples Republic of China. The price of "Zhangqiu Scallion" per kilogram was raised from 0.2-0.6 yuan before the use of the certification mark to 1.2-5 yuan in 2009 . "Jianlian" lotus seed was registered as a GI in 2006, leading to a rise in price from 26-28 yuan per kilogram to 32-34 yuan per kilogram. Clemens and Babcock [27] mention that although New Zealand lamb is protected indirectly as a geographical indication, although a premiere product, it has only managed to reach a premium price for a small percentage of exported produce. Menapace et al., [28] have observed the willingness of Canadian consumers to pay a premium price for origin branded olive oil.

In a study of the Indian rice GI, 'Basmati' and the Thai rice GI, 'Jasmine', Jena et al., [29] note that ability of these products to secure premium prices is also seen as an encouragement for securing 
external investment.

Although studies have suggested that GI products can capture premium prices, a particular problem for developing countries and LDCs is how to distribute these benefits from marketers to upstream to producers. For example, the producers of Zanzibari cloves receive $\$ 5$ per tonne, compared with the $\$ 40$ received by the distributors of those cloves in the lucrative European market [30]. Hughes [31] reports a generally negative experience of producers in Africa where the advantages premium prices from GIs tend to remain with centralised marketing authorities. Similar observations have been made by Gopalakrishnan et al., [32] in relation to Indian traders who have tended to securing the largest share of GI premiums, compared with producers.

\section{Certification of Product Quality}

GIs can play an important role in signalling the quality of goods to consumers [33]. Among the attributes of a product which are signalled by GIs is 'credence' or the integrity of product origin and sustainable production methods [34-36]. This is particularly the case where the GI is underpinned by a registration and certification system enabling producers to signal quality and an associated reputation that has been developed over time $[37,38]$. Claim that producers are incentivised by an origin indication to maintain product quality. The reputation signalled by the origin indication attaches to all stakeholders in the supply chain.

As consumers have become increasingly concerned with the quality, safety, and production features of food, the demand for food products with credence attributes (e.g., origin, organic, locally grown, environment-friendly) has been steadily growing [39]

Consumer food preferences that rely on credence attributes have become significant in industrialised countries. Consumers have indicated a willingness to pay a premium price for food products carrying a label identifying organic production, because of a concern with chemicals and pesticides in commercial food, and desire for increased taste and flavor [40]. Consumers have been identified as placing increasing value on the integrity of food, such as the social and environmental standards involved in the production and processing of agrifood products [41-43]. This is particularly the case following a number of food crises. As it is not unusual for food to be grown, processed and packaged in different places consumer trust in products is eroded, particularly as a consequence of these crises. Studies indicate a willingness of consumers to pay a premium price to producers who offer transparency in relation to the composition and origin of their products. In situations where uncertainty about quality or safety is elevated, such as in a health crisis, origin labelling can become an important means of inferring product quality, eg meat labels after the BSE crisis in Europe $[33,44,45]$ and dairy product labels after the Chinese Melamin crisis [46].

Developing and least developed countries are in an excellent position to meet the demand for credence products because of the prevalence of organic practices in their production. Thus, the marketing of both Darjeeling and Kenyan tea stress the absence of chemicals in their cultivation and hand, rather than machine picking of the leaves [47,48]. Among the reasons suggested for GI-marked goods attracting premium prices, is that consumers prize their exoticism and the greater care which has gone into their production compared with undifferentiated commodity products. Another factor is the increasing realisation that traditionally produced goods are often freer from contaminants, such as herbicides and pesticides and that GIs applied to these goods provides confidence in their traceability [49].

Rural product certification schemes have proliferated since the mid-1990s. They include the certification of organic agriculture, fairtrade certification of products from developing countries and food produced in compliance with sanitary and traceability protocols [41]. For smallholder producers in developing countries certification provides quality market niches at a time of declining agricultural and forest commodity prices.

GIs are identified as providing a means for the legal regulation of the use of origin product designations as a means of avoiding the deception of consumers as to the true origin of products, production methods and as to the specific quality of products [50,51]. In Europe, where GIs have been longest developed there are some empirically based suggestions that consumers' and producers both have expectations of about the quality of origin products in the European market [25].

\section{Aggregation of market power}

Gordon et al., [52] explain that to escape the commodity trap where each producer of a particular product is a direct competitor with every other producer, farmers need to band together both to differentiate their products and to aggregate their market power. This is particularly the case for agricultural producers in developing countries and LDCs, who are generally dwarfed by the industrialised country acquirers of their products. Yeung and Kerr [53] suggest that GIs are a useful modality for the aggregation of the market power of small producers. By creating grounds for competitive advantage based on territorial specificities and reducing competition with non-differentiated products, GIs potentially assist producers in appropriating a larger income from the production of origin-based goods [54]. Bramley and Biénabe [54] Point out that a niche marketing strategy entails an increase in production and marketing costs, particularly promotional costs to secure consumer recognition, but Barjolle and Sylvander [56] suggest that those promotional costs can be recouped through increased sales volumes and through premium product pricing. Belleti et al., [57] explain the international success of Tuscan firms producing: Olio Toscano PGI, Olio Chianti Classico PDO, Pecorino Toscano PDO and Prosciutto Toscano PDO to the aggregation of the market power of a number of small enterprises.

It should be noted however, that GI collectives in the EU in general have a long history of existence and have been created through local industry initiatives, which contrasts with. developing countries and LDCs where initiatives to establish GIs are driven by state instrumentalities, NGOs or agricultural universities, rather than by producer collectives. This lack of a tradition of collective action is seen to be a significant hurdle faced by developing country and LDCs in building a GI strategy [58].

\section{Sustainable use of natural resources and biodiversity conservation}

While environmental sustainability was not the primary aim of 
GIs protection, the fact that GIs are inextricably linked with local, natural resources means that the environmental benefits of origin products are increasingly seen as an important externality [59]. Responsible environment stewardship has also been mentioned by policymakers as a justification for GI protection [60].

The codes of practices which are collectively adopted in relation to GI labelling often incorporate biodiversity objectives [58]. Refer to the Rooibos industry in South Africa as an example of an industry which has explicitly considered biodiversity concerns in designing its product specification to take account of the environmental sensitivity of its place of production.

Belletti et al., [61] in their study of the European olive oil industry, which is characterised by an extensive use of GIs, identified this industry as an example of agriculture with many associated positive environmental impacts such as lower rates of soil erosion, improved fire-risk control, water efficiency, lower pollution and higher levels of biodiversity and genetic diversity in olive-tree varieties. Similarly, Kop et al., [62] pointed out that as the registered Comte cheese GI specifications limit the intensification of farming, so farmers use fewer inputs and the environment is better protected, contributing to maintaining the open landscape of both pasture and woodland that is typical of the Jura region in France. Profitable traditional livestock raising in the Comte area has limited the loss of pastureland to 7 percent in the designated GI area, compared with 18 percent in other cheese producing areas.

Guerra [63] observed that in the Mexcal region of Mexico the Agave sugar needed to make Tequila is cultivated and managed from wild or forest Agave species, which encourages the biodiverse Agave species. GIs can also serve as a tool for encouraging sustainable agricultural practice by legally limiting the scale of production and production methods. An activist role has been taken by the public authorities in developing GIs on behalf of agricultural communities. An example of this is the development by the Department of Horticulture $(\mathrm{DoH})$ of the government of Karnataka in India of a GI for Coorg orange (Kodagina kittale, Citrus reticulata), an ecotype of the mandarin orange [64]. This variety had almost disappeared because of diseases and lack of interest among farmers eager to involve themselves in more lucrative cash crops: coffee and pepper. The DoH filed a GI application for a 'Coorg Orange', which was registered in 2004. Among the objectives of the DoH were to protect and revive a traditional crop variety and to provide high quality (disease-free) plant material, bringing economic development to the region and protecting the ecosystem ecosystem where the orange is grown. The strategy of the DoH was to educate the local farmers about the GI and then to gather them in a registered society to which the ownership of the GI will be transferred.

In relation to sustainability objectives, it is also important to point out that the success of an origin product may lead to an increase in demand and therefore to increased pressure on local resources. Sustainable production guidelines need to be agreed upon by means of a participatory process in order to prevent pressure being placed on fragile environments and to ensure in particular that the GI does not lead to "genetic erosion" $[65,66]$.

\section{Rural Development}

One of the justifications advanced for the establishment of the
French GIs system for the protection of wines in the $19^{\text {th }}$ Century was the role that it played in preserving agriculture and rural employment in areas which were unsuitable for cereals and other crops [67]. The maintenance and promotion of rural development has been repeatedly advanced as a justification for GIs [50,68-71]. As Pacciani et al., [12] and O'Connor and Company [72] point out the protection of GIs accords with the EU policy on rural development. The Preamble to the 2006 EU GIs Regulation identified that:

The diversification of agricultural production should be encouraged so as to achieve a better balance between supply and demand on the markets. The promotion of products having certain characteristics can be of considerable benefit to the rural economy, particularly in less favoured or remote areas, by improving the incomes of farmers and by retaining the rural population in these areas".

The creation of local jobs through the protection of GIs is a factor influencing rural exodus [72], which is particularly important in developing countries and LDCs. Young people are considered the most disadvantaged in rural areas [73] and their departure from rural areas creates challenges to the sustainability of rural communities [74].

An increase in employment has for example been observed for the French Comte cheese industry [75]. Kop et al., [62] estimated that the production of Comte cheese generates five times more jobs in processing, maturing, marketing, packing, etc. than does its generic equivalents and that migration away from the countryside in the Comte area is only half that of equivalent cheese producing regions. Similar results have been identified for origin protected cheeses supporting the milk supply from cattle in Northern Italy and the sheep of Southern Italy [70]. Barjolle [51] identifies 21 European GIs where the maintenance of rural development is in the product specification. GIs also have a wider territorial impact that extends beyond the direct GI stakeholders. GIs can lead to employment creation and agro-tourism within the region. GIs are also likely to stimulate investment and the price of land within the borders of the GI region [54]. Giovannucci et al., [4] Also point to the potential "complementary effect" a GI may have on other products in the area.

In 2018 the African Union (AU) formulated a Continental Strategy for Geographic Indications (GIs) in Africa, 2018-2023 'to facilitate sustainable rural development in line with the vision of African leaders of a prosperous Africa based on inclusive growth and sustainable development' [76]. The AU envisaged that GIs for food and non-food products represent an answer to enhance exchanges among stakeholders at infra-national levels and thus to preserve and promote traditional products on local markets, as well as to position African export products better on international markets. In African countries, GIs can be used as a tool for the organization and promotion of agricultural value chains. They can create incomes for farmers and other stakeholders in the value chain, such as small processing units and petty traders, and therefore help them to face food lean periods and food and nutrition insecurity. Considerable work has been done in Africa to identify agricultural products that could benefit from GIs protection [15], including Burundi tea and coffee, Gambian cashews, Ugandan cotton and vanilla, shea butter from Burkina Faso, shallots from the Dogon area of Mali, rooibos tea 
from South Africa, Galmi onions from Niger, Fouta Djalon potatoes from Guinea and Madagascar Vanilla [77]. Already registered as GIs in Morocco the most advanced African country in this regard are Argane (oil), Clementine of Berkane, Majhoul Dates of Tafilalet, Pomegranate Sefri Ouled Abdellah, Prickly Pear of Aît Baâmrane, Chefch Aouen's Goat Cheese, Aziza Bouzid Dates of Figuig, Uphorbia Honey of Tadla-Azilal, Almonds of Tafraout, Boufeggous Dates, Midelt Apple, Medlars of Zegzel, Arbutus Honey of Jbal My Abdess Alam, Keskes Khoumassi, or Keskes Moukhamess, Extra Virgin Oil of Ouezzane, Safi Capers, Jihel Dates of Drâa, Azilal Walnut, Eastern Rosemary Dried Leaves, Eastern Rosemary Essential Oils, Doukkali Raisin, Rif Almonds, Ait Ouabelli Henna, Oued El Maleh Quince, Outat El Haj Olive Oil, Nabout Dry Fig of Taounate, Tafersite Olive Oil, Honey of Desert Euphorbia, Tyout Chiadma Olive Oil, Saffron of Taliouine, Rose of Kelâat M'gouna-Dadès, Extra Virgin Olive Oil Aghmat Aylane and Oulmes Lavender Essential Oils.

\section{Conclusion}

Considerable work has been done by the EU in identifying suitable GI candidates in the developing countries and LDCs of Africa, the Caribbean and the Pacific [7,72]. To some extent, this has reflected a European campaign to recruit supporters for its system of sui generis protection. Although, as we have seen above, there is a substantial literature on the potential benefits of GIs for developing countries and LDCs there is however, a paucity of empirical data on the positive impacts of GIs even in the EU.

The obligation imposed by the TRIPS Agreement for countries to implement GIs protection has resulted in considerable legislative activism around the world, but the top-down imposition of GIs laws has tended to run in advance of producer enthusiasm. For example, in India, although the Geographical Indications of Goods (Registration and Protection) Act was enacted in 1999 a study of Indian rice farmers in 2020 revealed a general ignorance of the difference between GIs and plant varieties [6].

The process of developing GIs in Europe has matured over many years and GIs are part of branding strategies, generating consumer familiarity and in which producers share in financial benefits with distributors. This is to be contrasted with developing countries and LDCs, where producer groups are usually state marketing boards and in which the benefits of premium prices do not often move down the distribution chain to producers.

In poorer countries the lack of market knowledge and financial resources to support the promotion of GI products is also a significant constraint [78] and it has been pointed out that the often ephemeral nature of consumer demand may make expensive marketing campaigns high risk investments [53,55]. In some countries, this expense can be defrayed if the promotion of GIs can be combined with the promotion of agri-tourism, or with seed funding provided from the national budget, such as that by the tourism authorities of Malaysia and Thailand.

Other costs which have to be carried include the expense of monitoring a GI and enforcing it against unauthorised third parties. In the early life of a GI, the expense of enforcement overseas can be carried by the national authorities. Thus, in relation to the misuse of the Indian GI 'Basmati' by a US corporation, proceedings were brought in the USA by CSIR, the national Indian scientific research authority [79-82]. Even in domestic litigation, the Tea Board of India has sued to defend the 'Darjeeling' GI.

As well as the financial burden, the implementation of GIs protection also imposes significant administrative burdens [12]. Point out that the capacity of GIs to assure rural development benefits is dependent upon the creation of institutions that govern the use of the GI, as well as preventing of misappropriation in domestic and international markets.

\section{References}

1. FAO. Food \& Agriculture Organization. The Role of Agriculture in The Development of Least-Developed Countries and their Integration into the World Economy. Rome, FAO. 2002.

2. World Bank. World Development Report 2008: Agriculture for Development, Washington, DC/Oxford, World Bank/Oxford University Press. 2007.

3. Dethier JJ, Effenberger A. Agriculture and development: A brief review of the literature, Economic Systems. 2012; 36: 175-205.

4. Giovannucci D, Barham E, Pirog R. Defining and marketing 'Local' foods: geographcial indications for US products. JWIP. 2010; 13: 94-120.

5. Blakeney M. The Protection of Geographical Indications. Law and Practice, $2^{\text {nd }}$ edition, Cheltenham UK, Edward Elgar. 2019.

6. Blakeney M, Krishnankutty J, Raju RJ, Siddique KMH. Agricultural Innovation and the Protection of Traditional Rice Varieties: Kerala a Case Study, Frontiers in Sustainable Food Systems. 2020; 3: 1-11.

7. EC (European Commission). Study on the potential for marketing agricultural products of the ACP countries using geographical indications and origin branding (ACP-AGGI). 2013.

8. Baggal N, Vittori M. Practical Manual on Geographical Indications for ACP Countries. CTA/origin. 2011.

9. Evans P. Geographic indications, trade and the functioning of markets Pugatch M, editors. In: The Intellectual Property Debate: Perspectives from Law, Economics and Political Economy. London, Edward Elgar. 2006; 345360.

10. Galtier F, Belletti G, Marescotti A. Are Geographical Indications a way to 'decommodify' the coffee market?, paper presented at $12^{\text {th }}$ Congress of the European Association of Agricultural Economists. 2008; 26-29.

11. Reviron S, Paus M. Special report: Impact analysis methods. WP2 Social and Economic Issues. SINER-GI project. European Commission Sixth framework program. 2006

12. Pacciani A, Beletti G, Marescotti A, Scaramuzzi S. The role of typical products in fostering rural development and the effects of regulation (EEC) 2081/92, $73^{\text {rd }}$ Seminar of the European Association of Agricultural Economists Ancona. 2001; 28-30.

13. Ittersum K, van Meulenberg MTG, van Trijp HCM, Candel MJJ. Consumers' appreciation of regional certification labels: a pan-European study, Journal of Agricultural Economics. 2007; 58: 1-23.

14. Durand C, Fournier S. Can Geographical Indications Modernize Indonesian and Vietnamese Agriculture? Analyzing the Role of National and Local Governments and Producers' Strategies, World Dev. 2017; 98: 93-104.

15. Blakeney M, Coulet T, Mengistie G, Mahop MT. Extending the protection of geographical indications: case studies of agricultural products in Africa. Abingdon, Oxon; New York, Routledge. 2012.

16. Sautier D, Bienabe E, Cerdan C. Geographical Indications in Developing Countries: The Potential and the Issues. Barham E and Sylvander B, editors. In: Labels of Origin for Food, Local Development, Global Recognition. Wallingford, CABI International. 2011; 138-153.

17. Schroeder K. The Case of Blue Mountain Coffee, Jamaica. Giovannucci D, editors. In: Guide to Geographical Indications Linking Products and Their Origins. Geneva, International Trade Centre. 2009; 170-176. 
18. Reviron S, Thevenod-Mottet E, El Benni N. Geographical indications: creation and distribution of economic value in developing countries. Zurich, NCCR. 2009; 14

19. Marette S. 'The Collective-Quality Promotion in the Agribusiness Sector: An Overview' Working paper 05-WP406 Centre for Agricultural and Rural Development. Iowa State University. 2005

20. Williams RM. Do Geographical Indications Promote Sustainable Rural Development: Two UK case studies and implications for New Zealand rural development policy. Lincoln University. 2007

21. Babcock BA. Geographical Indications, Property Rights, and Value-Added Agriculture, lowa Ag Review. 2003; 9

22. Gerz A, Dupont F. Comte Cheese in France: Impact of a Geographica Indication on Rural Development. van de Kop P, Sautier D, Gerz A, editors. In: Origin-Based Products: Lessons for Pro-Poor Market Development. Amsterdam, KIT Publishers. 2006; 75-87.

23. MAAPAR. Impact d'une indication geographique sur l'agriculture et le developpement rural: le fromage de Comte-France. Ministère de l'agriculture, de l'alimentation, des peches et des affaires rurales, Paris. 2004.

24. O'Connor \& Co. Geographical Indications and the Challenges for ACP Countries. Agritrade, CTA. 2005.

25. Teuber R. Producers' and Consumers' Expectations towards Geographical Indications - Empirical Evidence for Hessian Apple Wine. paper prepared for presentation at the $113^{\text {th }}$ EAAE Seminar "A resilient European food industry and food chain in a challenging world, Chania, Crete, Greece. 2009.

26. Kireeva I, Xiaobing W, Yumin Z. Comprehensive Feasibility Study for Possible Negotiations on a Geographical Indications Agreement between China and the EU, Brussels. EU-China IP2. 2009.

27. Babcock BA, Clemens R. Geographical Indications and Property Rights: Protecting Value-Added Agricultural Products. Center for Agricultural and Rural Development (CARD) at lowa State University. 2004.

28. Menapace L, Colson G, Grebitus C, Facendola M. Consumer preferences for country of origin, geographical indication, and protected designation of origin labels. Working Paper No. 09021, lowa State University, Department of Economics. Ames, lowa. 2009

29. Jena PR, Ngokkuen C, Rahut DB. Grote U. Geographical indication protection and rural livelihoods: insights from India and Thailand. Asian-Pacific Economic Literature, Asia Pacific School of Economics and Government. The Australian National University. 2015; 29: 174-185.

30. Blakeney M, Mengistie G. Case Study-Zanzibar Cloves. Blakeney M Coulet T, Mengistie G, editors. In: Extending the Protection of Geographica Indications. Case Studies in the Protection of Agricultural Products in Africa, London, Earthscan. 2012b; 7-34.

31. Hughes J. Coffee and chocolate: Can we help developing country farmers through geographical indications? Washington DC, International Intellectual Property Institute. 2009.

32. Gopalakrishnan NS, Nair PS, Babu AK. Exploring the relationship between geographical indications and traditional knowledge: An analysis of the legal tools for the protection of geographical indications in Asia, Geneva, ICTSD. 2007.

33. Becker T. European food quality policy: the importance of geographica indications, organic certification and food quality insurance schemes in European countries. The Estey Centre Journal of International Law and Trade Policy. 2008; 10: 111-130.

34. Bonanno A, Bimbo F, Costanigro M. Lansink AO, Viscecchia R. Credence attributes and the quest for a higher price-A hedonic stochastic frontier approach. European Rev Agric Econ. 2019; 46: 163-192.

35. Dahlhausen JL, Rungie C, Roosen J. Value of labeling credence attributescommon structures and individual preferences. Agric Econ. 2018; 49: 741 751.

36. Yang W, Renwick A. A Consumer Willingness to Pay Price Premiums for Credence Attributes of Livestock Products-A Meta-Analysis. J Agric Econ. 2019; 70: 618-639.
37. Winfree JA, McCluskey J. Collective Reputation and Quality. Am J Agric Econ. 2005; 87: 206-213

38. Moschini G, Menapace L, Pick D. Geographical indications and the provision of quality in agricultural markets. Am J Agric Econ. 2008; 90: 794-812.

39. Dentoni D, Tonsor GT, Calantone RJ, et al. The Direct and Indirect Effects of 'Locally Grown' on Consumers' Attitudes towards Agri-Food Products. Agric and Res Econ Rev. 2009; 38: 384-396.

40. Baker GA. Consumer Preferences for Food Safety Attributes in Fresh Apples: Market Segments, Consumer Characteristics, and Marketing Opportunities. J Agric and Res Econ. 1999; 24: 80-97.

41. Giraud G, Amblard C. What does traceability mean for beef meat consumer? Food Sci. 2003; 23: 40- 46.

42. Renting H, Marsden TK, Banks J. Understanding Alternative Food Networks: Exploring the Role of Short Food Supply Chains in Rural Development. Env and Planning A. 2003; 35: 393-411.

43. Hobbs JE, Bailey D, Dickinson DL, et al. Traceability in the Canadian Red Meat Sector: Do Consumers Care? Can J Agric Econ. 2005; 53: 47-65.

44. Verbeke W, Viaene J. Consumer attitude to beef quality labeling and associations with beef quality labels. J Int Food and Agribusiness Marketing 1999; 10: 45-65.

45. Lees M. Food Authenticity and Traceability, Cambridge. Woodhead Publishing. 2003

46. Xu L, Wu L. Food safety and consumer willingness to pay for certified traceable food in China. J Sci Food Agric. 2010; 90: 1368-1373.

47. Besky S. The labor of terroir and the terroir of labor: Geographical Indication and Darjeeling tea plantations, Agric. and human values. 2014; 31: 83-96.

48. Blakeney M, Mengistie G. Case Study: Kenya Tea. Blakeney M, Coulet T Mengistie G, editors. In: Extending the Protection of Geographical Indications. Case Studies in the Protection of Agricultural Products in Africa, London, Earthscan. 2012a; 213-234.

49. Blakeney M. Geographical Indications and Environmental Protection, Frontiers of Law in China. 2017; 12: 162-173.

50. Tregear A, Arfini F, Belletti G, Marescotti A. Regional foods and rural development: The role of product qualification. J Rur Studs. 2007; 23: 12-22.

51. Barjolle D. Geographical Indications and protected designations of origin: intellectual property tools for rural development objectives. Gangjee DS, editors. In: Research Handbook on Intellectual Property and Geographical Indications, Cheltenham UK, Edward Elgar. 2016; 440-462.

52. Gordon DV, Hannesson R, Kerr WA. What is a Commodity? An Empirica Definition Using Time Series Econometrics. J Int Food and Agribusiness Marketing. 1999; 10: 1-29.

53. Yeung MT, Kerr WA. Are geographical indications a wise strategy for developing country farmers? Greenfields, clawbacks and monopoly rents. JWIP. 2011; 14: 353-367.

54. Zografos D. Geographical Indications and Socio-Economic Development IQsensato Working Paper No 3. 2008.

55. Bramley C, Bienabe E. Developments and considerations around geographical indications in the developing world, Queen Mary Journal of Intellectual Property. 2012; 2: 14-37.

56. Barjolle D, Sylvander B. Some factors of success for origin labelled products in Agro-food supply chains in Europe: market, internal resources and institutions. Economies et Societes. 2002; 25: 1441-1464.

57. Belletti G, Burgassi T, Marescotti A. Silva S. The effects of certification costs on the success of a PDO/PGI. Theuvsen L, Spiller A, Peupert M, editors. In: Quality Management in Food Chains, Wageningen, Wageningen Academic Publishers. 2007; 107-121.

58. Bienabe E, Leclercq M, Maizi, PM. Le rooibos d'Afrique du Sud: comment la biodiversité s'invite dans la construction d'une indication géographique. Autrepart. 2009; 50: 117-134. 
59. Thevenod-Mottet F. Geographical indications and biodiversity. Lockie S Carpenter D, editors. In: Agriculture, biodiversity and markets. Livelihoods and agroecology in comparative perspective, London, Earthscan. 2020; 201 213.

60. EC (European Commission). Conclusions from the consultation on agricultural product quality' Brussels, Directorate-General for agriculture and rural development. 2009

61. Belletti G, Marescotti A, Sanz-Canada J, Vakoufaris H. Linking protection of geographical indications to the environment: Evidence from the European Union olive-oil sector, Land Use Policy. 2015; 48: 94-106.

62. Kop P, van de Sautier D, Gerz A. Origin-Based Products. Lessons for propoor market development, Amsterdam, Royal Tropical Institute (KIT). 2006.

63. Guerra JL. Geographical Indications and Biodiversity: Bridges Joining Distant Territories. Bridges. 2004; 2: 17-18

64. Garcia C, Marie-Vivien D, Kushalappa CG, Chengappa PG, Nanaya KM Geographical Indications and Biodiversity in the Western Ghats, India Mountain Res and Dev. 2007; 27: 206-210.

65. Downes D, Laird SA. Innovative Mechanisms for Sharing Benefits of Biodiversity and Related Knowledge-Cases Studies on Geographical Indications and Trademarks, Geneva. UNCTAD Biotrade Initiative. 1999.

66. Boisvert V. From the conservation of genetic diversity to the promotion of quality foodstuff. Can the French model of Appellation d'Origine Controlee be exported? (Collective Action and Property Rights Working Paper no 49), Washington DC. International Food Policy Research Institute (IFPRI). 2006.

67. Stanziani A. Wine Reputation and Quality Controls: The Origin of the AOCs in $19^{\text {th }}$ Century France. Eur J Law and Econ. 2004; 18: 149-167.

68. Ray C. Culture, Intellectual Property and Territorial Rural Development. Sociologia Ruralis. 1998; 38: 3-20.

69. Marsden T, Banks J, Bristow G. Food Supply Chain Approaches: Exploring their role in Rural Development. Sociologia Ruralis. 2000; 40: 424-438.

70. Belletti G, Marescotti A. Link between Origin-Labeled Products and Rura Development, WP Report 3. Development of Origin-Labeled Products: Humanity, Innovations, and Sustainability (DOLPHINS) project. Le Mans. 2002.

71. Belletti G, Marescotti A. Origin Products, Geographical Indications and
Rural Development. Barham E, Sylvander B, editors In: Labels of Origin for Food. Local Development, Global Recognition. Wallingford, Oxford, CAB International. 2011

72. O'Connor \& Co. Geographical Indications and the Challenges for ACP Countries. Agritrade, CTA. 2005

73. Chapman $P$, Shucksmith M. The Experience of Poverty and Disadvantage in Rural Scotland, Scottish Geographical Magazine. 1996; 112: 70-76.

74. Jentsch B. Youth Migration from Rural Areas: Moral Principles to Support Youth and Rural Communities in Policy Debates. Sociologia Ruralis. 2006; 46: 229-240.

75. Requillart V. On the economics of geographical indications in the EU. Paper presented at a workshop on Geographical indications, country of origin and collective brands: firm strategies and public policies. Toulouse June. 2007 14-15.

76. African Union. Continental Strategy for Geographical Indications in Africa, 2018-2023, Addis Ababa, African Union Department of Rural Economy and Agriculture. 2018

77. Mengistie G, Blakeney M. Geographical Indications in Africa. Opportunities, Experiences and Challenges'. EIPR. 2016; 38: 290-306.

78. CIRAD. The challenges relating to Geographical Indications (GIs) for ACP countries, Joint CTA, AFD and CIRAD workshop report Montpellier. 2009; 24-27.

79. Lightbourne M. Of Rice and Men: An Attempt to Assess the Basmati Affair. JWIP. 2003; 6: 875-894.

80. Bienabe E, Bramley C, Kirsten J. Trockie DPet al. Linking farmers to markets through valorisation of local resources: the case for intellectual property rights of indigenous resources, Reports 108283, University of Pretoria, Department of Agricultural Economics. Extension and Rural Development. 2010.

81. Bowen S. Development from within? The potential for geographical indications in the global South. JWIP. 2010; 13: 231-252.

82. Towards a Conceptual Framework for Geographical Indication Research in Developing Countries in WIPO. The Economics of Intellectual Property. Suggestions for Further Research in Developing Countries and Countries with Economies in Transition. 